\title{
Validation of a Semi-Empirical Procedure for Estimating Steady-State, Groundwater Inflows in Shallow Rock Tunnels Through Case Study Analyses
}

Mark J. Vanarelli ( $\square$ markvanarelli@gmail.com )

Colorado School of Mines https://orcid.org/0000-0003-1473-6791

\section{Research Article}

Keywords: Groundwater Inflows, Shallow Rock Tunnels, Vertical Recharge Conditions, Tunnel Water.

Posted Date: June 1st, 2021

DOI: https://doi.org/10.21203/rs.3.rs-456275/v1

License: (c) (7) This work is licensed under a Creative Commons Attribution 4.0 International License. Read Full License 


\section{Abstract}

The construction of underground excavations and tunnels can only be done safely and economically when the subsurface conditions are adequately understood. Excessive groundwater inflows into rock tunnels under construction can injury personnel and terminate the construction of the tunnel project. Therefore, it is important to accurately estimate groundwater inflows into rock tunnels. A semi-empirical procedure/method for estimating steady-state, groundwater inflows in shallow rock tunnels is presented and discussed in this paper. In addition, this paper presents two case study analyses which include the Elizabethtown tunnel in New Jersey and the Toledo tunnel in Ohio. Packer test (i.e., pressure test) data was analyzed for both case studies utilizing this semi-empirical procedure. This paper reviews the theory behind the procedure, summarizes validates the procedure through case study analyses. It also describes previous proposed modifications and clarifies the need for any such modifications. In general, good groundwater inflow estimates were derived for shallow rock tunnels utilizing this semi-empirical procedure/method.

\subsection{Introduction}

The construction of tunnels in rock has increased in importance in the United States, as well as other nations, as the need for new transportation routes and water/wastewater conveyances has grown. Large cities and nearby suburbs have limited space for extensive, above-ground thoroughfares; therefore, underground systems may be the only viable means for developing new infrastructure [13].

Historically, engineering geologists and geotechnical engineers have estimated groundwater inflow utilizing concepts and formulae developed by Goodman et al. (1964) who treated the ground as homogeneous and the tunnel as a groundwater well. The state of the practice to estimate groundwater inflows into rock tunnels is to apply Heuer's semi-empirical procedure/method. This procedure uses packer test data from borings to determine equivalent permeability of the rock formation $[5,7,13]$.

This paper describes the geological and geotechnical conditions in two case studies and utilizes the data to test the procedure and verify the estimates of steady state, groundwater inflows in these two tunnel projects [13].

\subsection{Background}

Much of our understanding of groundwater flow is based on experiments in the nineteenth century conducted by a French engineer named Henry Darcy. Darcy studied the movement of water through a porous medium. It was not until the mid- $20^{\text {th }}$ century that researchers began to develop different approaches that could be used to estimate groundwater inflow to tunnels in rock $[4,13]$.

Numerous researchers have proposed various analytical, empirical, semi-empirical, and numerical methods/procedures for estimating steady-state groundwater inflows into rock tunnels $[1,3,6,7,10,11-13]$. These methods can produce varying results. The accuracy of all these methods is highly dependent on the quality of field data that characterize the geological and hydrogeological systems above, below and through which the tunnel is being constructed [13].

Goodman et al. developed mathematical approaches using computer and physical models to describe groundwater inflow into rock tunnel for a variety of situations. In most of these cases, they characterized fractured rock systems as a hydraulically equivalent and homogenous medium by utilizing data from water pressure tests from drill holes. From these drill hole tests, they approximated the permeability of the rock formation $[5,13]$.

Heuer (1995) developed a semi-empirical procedure/method for estimating steady-state, groundwater inflows in rock tunnels. He used data collected from water pressure tests or packer tests to generate histograms. Testing was conducted with inflatable straddle packers at 10 to 20 foot (3 to 6 meter) spacing throughout the borehole depth and below the water table. The primary geologic factors that affect groundwater inflows were the presence of imperfections or defects in the rock mass through which water may flow. Heuer divides these factors into two categories: point sources of local, large inflow such as lava tubes or major solution features, and distributed features that are common throughout the rock mass such as interconnected joints and fractures, bedding planes, and fault systems (i.e., sometimes referred to as discontinuity features). Heuer focuses exclusively on these distributed features $[5,7,13]$.

Heuer (1995) did not distinguish between hydraulic conductivity (i.e., K) and permeability (i.e., $\mathrm{k}_{\mathrm{i}}$ ) in his work. This assumption is reasonable since the medium of study is groundwater (i.e., as opposed to petroleum hydrocarbons) and temperatures in the subsurface do not vary greatly in the continental United States. It should be recognized that the hydraulic conductivity and permeability differ by the following relationship: 
where $K$ is hydraulic conductivity, $k$ or $k_{\mathrm{i}}$ is intrinsic permeability, $\rho$ is the density of water, $g$ is gravity, and $\mu$ is the dynamic viscosity. Heuer (1995) referred to "equivalent permeability" or $k_{e}$, as the characteristic of the rock mass derived from standard analysis of packer test data. Equivalent permeability describes the rate of water flow through a fractured rock mass, as opposed to, the rate of water flow through a relatively homogeneous, isotropic, porous medium such as sand where water flows through interconnected voids between the sand particles (i.e., intrinsic permeability). Unless otherwise denoted, this paper and the analyses included herein address issues related to equivalent permeability $[7,8,13]$.

In this paper, only the long-term, steady-state case will be considered. For practical analysis purposes, the steady state case can be reduced to two conceptual models that contribute groundwater inflow to rock tunnels. These two models include the vertical recharge with a nearby water source at constant head (e.g., a tunnel overlain by a lake or reservoir) and radial flow with a recharge source far away. More specifically, for the vertical recharge flow condition to be established, the tunnel must be near or within two diameters of the top of bedrock and a water body must be present and whose piezometric surface cannot be depressed or drawn down. Therefore, the vertical recharge conditions can most closely be associated with shallow rock tunnels. For the radial flow condition, the tunnel is typically several tunnel diameters below the top of rock with limited hydraulic communication with overlying surface water. Therefore, the radial flow condition can most closely be associated with deep rock tunnels. These two models are conceptually shown in Figure 1 and can be applied using the following equations for the vertical recharge and radial flow cases [5, 7, 13-15].

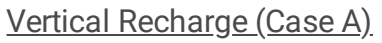

$$
q_{s}=\frac{2 \pi}{\ln \left[\frac{2 z}{r}\right]} K H
$$

where $z=$ thickness of rock cover between tunnel and water source, $z<20$ r (i.e., 10 tunnel diameters).

Radial Flow ( $\underline{\text { Case B }}$.

$$
q_{s}=\frac{2 \pi}{\ln \left(R_{0} / r\right)} K H
$$

where $z>20$ r (i.e., 10 tunnel diameters), $H=$ water head from piezometric surface, $K=$ mass permeability or hydraulic conductivity, $q_{s}=$ volumetric inflow per unit length of tunnel, $R_{O}=$ radius of influence, distance to which piezometric head is influenced by the tunnel. Heuer's semi-empirical procedure is summarized at the end of Table 2 and utilizes the chart shown in Figure $2[7,14,15]$.

\subsection{Proposed Modifications}

In 2005, Heuer provided additional case study analyses and commented on his previous works. In this paper, he discussed and analyzed the Elizabethtown Tunnel Project in New Jersey. The tunnel crosses under the Delaware and Raritan Canal and the Raritan River which would indicate that it should be analyzed for the vertical recharge condition, but Heuer decided to analyze some parts for the vertical recharge conditions while other parts for the radial flow condition. Heuer estimated that water inflow into the tunnel would be $66 \mathrm{gpm}$ (gallons per minute) or $246 \mathrm{~L} / \mathrm{min}$ (liters per minute) as summarized in Table 1 . The observed inflow rate was $100 \mathrm{gpm}$ (378 L/min). The observed inflow was 1.5 times higher than the estimated value derived from Heuer's 2005 analysis [7, 13].

Table 1: Summary of Steady-State(SS), Groundwater Inflows [13] 


\begin{tabular}{|lllc|}
\hline Project Name & & Elizabethtown & Toledo \\
\hline Variables & Geological Formation: & Red Shale & Dolomite \\
\hline L & Parameter & & \\
\hline$r_{0}$ & Tunnel Length (ft) & 1,225 & 1,500 \\
\hline z & Tunnel Radius (ft) & 4.25 & 4.5 \\
\hline Soil Conditioning & Distance/Top of rock (ft) & 15 & 23 \\
\hline Full Length Completed & Grouted & No & No \\
\hline Flow Condition & & Yes & Yes \\
\hline Heuer's Estimate based on 2005 Paper & SS Inflow Rate (gpm) & 66 & 50 \\
\hline Steady State Groundwater Inflow Estimate & SS Inflow Rate (gpm) & 99 & 30 \\
& & & Vertical \\
\hline utilizing Semi-empirical Procedure (1995) & & & $\mathbf{3 0}$ \\
\hline Observed Inflows (Qs) & & & \\
\hline
\end{tabular}

In Heuer's 2005 paper, he compared this case study to other case studies where the radial flow condition exists and noted that the procedure also underestimated the groundwater inflows. He also noted that the observed inflows for all case studies cited were approximately 1.5 times larger than estimated values on average, and suggested, in order to improve the accuracy of estimates, using the upper boundary of each equivalent permeability bin when estimating the normalized steady state inflow intensity in Figure 2 . This is equivalent to adjusting the 1995 analysis procedure upwards by a factor of 1.5 . Heuer decided to apply this "correction factor" to both flow conditions $[8,13]$.

Heuer's semi-empirical method appeared to underestimate groundwater inflows for both flow conditions and with the same relative magnitude. However, case study analyses in the following sections will show that this is not correction $[8,13]$.

\subsection{Case Studies}

\subsection{Elizabethtown Tunnel Project in New Jersey}

To improve the regional water supply system, the Elizabethtown Water Company (EWC) approved a program to upgrade the water conveyance system which included the extension of a 6-foot (1.8-meter) diameter \transmission main from South Bound Brook to Middlesex Borough in New Jersey. A 1225-foot (373-meter) tunnel was constructed as part of the transmission main under the Delaware and Raritan (D\&R) Canal and the Raritan River $[9,13]$.

The D\&R Canal traverses 44 miles (71 kilometers) from Bordentown on the Delaware River to New Brunswick on the Raritan River. The canal contains 14 locks which serve to overcome an elevation change of 115 feet (35 meters). It was used for industrial and commercial development in the early part of the 19th century. Many boats and barges were used to transport various goods on the canal. Today, the canal and its banks have been designated as a state park which is mainly used for recreational activities. The canal still serves as a water supply to over $1 \frac{1}{2}$ million people $[9,13]$.

The tunnel consisted of an excavated diameter of 8.5 feet ( 2.6 meters). The tunnel was circular and excavated using a Tunnel Boring Machine (TBM). Generally, the average depth of the tunnel is approximately 35 feet (11 meters) below ground surface. The top of rock is approximately 15 feet (4.6 meters) above the center of the tunnel. A water table, unconfined aquifer exists above the top of rock in the glacial outwash and fill. Groundwater from the water table aquifer is within 10 to 15 feet ( 3.0 to 4.6 meters) below the ground surface in most places. Groundwater from the water table aquifer is interconnected with the surface water system including the D\&R canal and the Raritan River. Rock discontinuities have been recorded in rock cores from borings and are presumed to be a conduit for groundwater flow from the water table aquifer into the bedrock formation. These discontinuities have been observed in the Passaic Formation as joints, faults, bedding planes and weathered zones. No faulting was observed in the borings or in an aerial investigation of the tunnel area $[9,13]$. 
The geology of Northern New Jersey in the project area consists of sedimentary rocks formed in the Lower Jurassic and Upper Triassic eras. Specifically, siltstones and shales of the Passaic Formation are the primary rock type in the project areas. A major intrabasinal fault system exists in the project area. The project is in the Piedmont Physiographic Province of North America. It is on the southern edge of the Wisconsin terminal moraine. The project site is underlain by glacial outwash such as fine sands, silty sands, silts, and clays and bedrock, consisting of reddish-brown to brown-purple and grayish-red siltstones and shales $[9,13]$.

\subsubsection{Analysis of Data from the Elizabethtown Tunnel}

The Elizabethtown Tunnel is constructed in red shale of the Passaic Formation. There are two constant-head water bodies, the Delaware and Raritan Canal and the Raritan River, which overlie the tunnel. The water bodies lie within 50 feet (15.2 meters) above the center of the tunnel. Therefore, the tunnel should be analyzed as a vertical recharge flow condition case. A total of 6 packer tests were performed in the rock formation $[9,13]$.

As part of this paper, an independent analysis was conducted based on raw/original data and the histogram was created as shown as Fig. 3. This analysis as conducted with raw data from packer tests yields an estimated steady state inflow of $99 \mathrm{gpm}(374 \mathrm{~L} / \mathrm{min})$ as presented in Table 2, which is consistent with observed inflows of $100 \mathrm{gpm}(378 \mathrm{~L} / \mathrm{min})$ as summarized in Table 1. This analysis applied vertical recharge conditions along the entire length of the tunnel which was 1225 feet (373-meter). In this analysis, the tunnel was not segmented nor were differing flow conditions applied for each segment of the tunnel as Heuer had done in his 2005 analysis. More specifically, Heuer applied the vertical recharge conditions to only a part of the tunnel that lied directly under the water body (i.e., approximately 325 feet or 99 meters). The rest of the tunnel, approximately 900 feet ( 274 meters), was analyzed using the radial flow conditions. Based on a comparison of these analyses, the entire 1225-foot (373-meter) length of tunnel should have been analyzed using vertical recharge conditions $[9,13]$.

\subsection{Toledo Tunnel Project in Ohio}

The City of Toledo, Department of Public Utilities, Division of Engineering Services approved the Phase II East Side Trunk Water Main Project to improve the water supply system. This project included several miles of additional water mains to supply water to the municipality. As part of this project, a tunnel was constructed which crosses under the Maumee River. The tunnel is approximately 1500 feet (457 meters) long and has an excavated diameter of 9 feet (2.7 meters). The tunnel was excavated via TBM $[2,13]$.

The project site is in the Huron-Erie Lake Plain Physiographic Region of Ohio, or specifically, the Maumee Lake Plain. The project area is underlain by glacial deposits from the Pleistocene Epoch, Quaternary Period. These deposits consist of lacustrine sand and clays [2, 13]. The banks of the river are composed of these glacial deposits.

Table 2 - Elizabethtown Tunnel Project - Distribution of Groundwater Inflows Heuer's Procedure using Raw Data [13] 


\begin{tabular}{|c|c|c|c|c|c|c|c|c|c|c|c|}
\hline A & B & $C$ & D & $E$ & $\mathrm{~F}$ & G & $\mathrm{H}$ & 1 & $\mathrm{~J}$ & $K$ & $L$ \\
\hline \multirow[t]{4}{*}{ Bin } & \multirow{4}{*}{$\begin{array}{l}\text { Bin } \\
\text { Labels }\end{array}$} & \multirow[t]{4}{*}{ Frequency } & \multirow{4}{*}{$\begin{array}{l}\text { Fraction } \\
\text { Of } \\
\text { Inflow } \\
\text { in } \\
\text { Tunnel } \\
\text { Interval }\end{array}$} & \multirow{4}{*}{$\begin{array}{l}\text { Length } \\
\text { Of } \\
\text { Tunnel } \\
\text { (m) }\end{array}$} & \multirow{4}{*}{$\begin{array}{l}\text { Fraction } \\
\text { Of } \\
\text { Tunnel } \\
\text { Length } \\
\text { (m) }\end{array}$} & \multirow{4}{*}{$\begin{array}{l}\text { Equivalent } \\
\text { Permeability } \\
\text { (cm/sec) }\end{array}$} & \multirow{4}{*}{$\begin{array}{l}\text { Constant } \\
\left(\mathrm{q}_{\mathrm{s}} / \mathrm{H}\right)\end{array}$} & \multirow{4}{*}{$\begin{array}{l}\text { Head } \\
(\mathrm{m})\end{array}$} & \multirow{4}{*}{$\begin{array}{l}\mathrm{q}_{\mathrm{s}} \\
(\mathrm{L} / \mathrm{min} / \mathrm{m})\end{array}$} & \multirow{4}{*}{$\begin{array}{l}\text { Steady } \\
\text { State } \\
\text { Inflow } \\
\text { (L/min) }\end{array}$} & \multirow{4}{*}{$\begin{array}{l}\text { Steady } \\
\text { State } \\
\text { Inflow } \\
\text { (gpm) }\end{array}$} \\
\hline & & & & & & & & & & & \\
\hline & & & & & & & & & & & \\
\hline & & & & & & & & & & & \\
\hline Less & $\begin{array}{l}<1.0 \mathrm{E}- \\
06\end{array}$ & 0 & 0.00 & 373 & 0 & $6.50 \mathrm{E}-07$ & 1.30E-04 & 8 & $1.04 \mathrm{E}-03$ & 0 & 0 \\
\hline $\begin{array}{l}3.00 \mathrm{E}- \\
06\end{array}$ & $\begin{array}{l}1.0 \mathrm{E}- \\
06 \text { to } \\
3.0 \mathrm{E}- \\
06\end{array}$ & 0 & 0.00 & 373 & 0 & $2.00 \mathrm{E}-06$ & 4.00E-04 & 8 & $3.20 \mathrm{E}-03$ & 0 & 0 \\
\hline $\begin{array}{l}1.00 \mathrm{E}- \\
05\end{array}$ & $\begin{array}{l}3.0 \mathrm{E}- \\
06 \text { to } \\
1.0 \mathrm{E}- \\
05\end{array}$ & 0 & 0.00 & 373 & 0 & $6.50 \mathrm{E}-06$ & $1.30 \mathrm{E}-03$ & 8 & $1.04 \mathrm{E}-02$ & 0 & 0 \\
\hline $\begin{array}{l}3.00 \mathrm{E}- \\
05\end{array}$ & $\begin{array}{l}1.0 \mathrm{E}- \\
05 \text { to } \\
3.0 \mathrm{E}- \\
05\end{array}$ & 0 & 0.00 & 373 & 0 & $2.00 \mathrm{E}-05$ & $4.00 \mathrm{E}-03$ & 8 & $3.20 \mathrm{E}-02$ & 0 & 0 \\
\hline $\begin{array}{l}1.00 \mathrm{E}- \\
04\end{array}$ & $\begin{array}{l}3.0 \mathrm{E}- \\
05 \text { to } \\
1.0 \mathrm{E}- \\
04\end{array}$ & 1 & 0.17 & 373 & 62 & $6.50 \mathrm{E}-05$ & 1.30E-02 & 8 & 1.04E-01 & 6 & 1.7 \\
\hline $\begin{array}{l}3.00 \mathrm{E}- \\
04\end{array}$ & $\begin{array}{l}1.0 \mathrm{E}- \\
04 \text { to } \\
3.0 \mathrm{E}- \\
04\end{array}$ & 2 & 0.33 & 373 & 124 & $2.00 \mathrm{E}-04$ & 4.00E-02 & 8 & 3.20E-01 & 40 & 10.5 \\
\hline $\begin{array}{l}1.00 \mathrm{E}- \\
03\end{array}$ & $\begin{array}{l}3.0 \mathrm{E}- \\
04 \text { to } \\
1.0 \mathrm{E}- \\
03\end{array}$ & 2 & 0.33 & 373 & 124 & $6.50 \mathrm{E}-04$ & 1.30E-01 & 8 & $1.04 \mathrm{E}+00$ & 129 & 34.2 \\
\hline $\begin{array}{l}3.00 \mathrm{E}- \\
03\end{array}$ & $\begin{array}{l}1.0 \mathrm{E}- \\
03 \text { to } \\
3.0 \mathrm{E}- \\
03\end{array}$ & 1 & 0.17 & 373 & 62 & 2.00E-03 & 4.00E-01 & 8 & $3.20 \mathrm{E}+00$ & 199 & 52.6 \\
\hline More & $\begin{array}{l}>3.0 \mathrm{E}- \\
03\end{array}$ & $\begin{array}{l}\text { Not } \\
\text { Observed }\end{array}$ & & & & & & & & & \\
\hline Total & & 6 & 1.00 & & 373 & & & & $\begin{array}{l}\text { Total } \\
\text { Inflow = }\end{array}$ & 374 & 99 \\
\hline
\end{tabular}

Note: Summary for Steady-State GW Inflow with Heuer's 1995 Procedure with Raw Data is as follows:

Step 1. Obtain raw packer testing data from the geotechnical investigation and sort the occurrence of this data into individual bin intervals to determine the frequency; insert results into Column $\mathrm{C}$ of Table 2.

Step 2. Determine the Fraction of Inflow into the Tunnel (Column D) by dividing the frequency (Column C) by the total number of tests.

Step 3. Determine Fraction of Tunnel Length (Column F) by multiplying Column D by Column E (i.e., total length of the tunnel, already known).

Step 4. Obtain the average Equivalent Permeability (Column G) in a specific bin interval from Fig. 2 (Vertical Recharge Flow).

Step 5. Obtain constant $\left(\mathrm{q}_{\mathrm{s}} / \mathrm{H}\right)$ along the $\mathrm{y}$-axis of Fig. 2; Insert in Column $\mathrm{H}$.

Step 6. Insert known average total head for the entire length of tunnel in Column I.

Step 7. Multiply Columns $\mathrm{H}$ and I: Insert the result in Column $\mathrm{J}\left(\mathrm{q}_{\mathrm{s}}\right)$. 
Step 8. Multiply Columns $\mathrm{J}$ and $\mathrm{F}$ and insert the result in Column $\mathrm{K}(\mathrm{SS}$ Inflow (L/min)).

Step 9. Convert Column K into gallon per minute by multiply by 0.2643 ; Insert the resultant in Column L(SS Inflow (gpm)[7, 13$]$.

The riverbed consists of a thin veneer of fluvial sediment. The bedrock geology, which underlies these glacial deposits and fluvial sediments, consists of dolomite. Dolomite is a crystalline sedimentary rock, which is largely composed of marine organisms such as clams and corals mixed with sand, silt, and clay. Dolomite is like limestone in composition, except that dolomite contains magnesium. Dolomite is less likely to possess internal drainage, collapse features or solution cavities (i.e., karst features). This dolomite is horizontally bedded. The dolomite observed in this site investigation belongs to one of two formations: the Greenfield Dolomite (younger) or the Guelph Dolomite (older) [2, 13].

The Toledo tunnel is in the Greenfield Dolomite approximately 30 feet ( 9 meters) below the river and 25 feet (7.6 meters) below the top of the bedrock. Packer testing was completed in ten borings. A total of nineteen packer tests were performed to determine the bedrock permeability $[2,13]$.

The Greenfield Dolomite is part of the Cayugan Series of the Salina Group. It can be described as an argillaceous dolomite, varying from an olive-gray to yellow brown color with thin to thick beds. This dolomite has an overall thickness of less than 80 feet. The Greenfield Dolomite is vuggy in some place and may contain petroleum and asphalt filled cavities in some areas. Some slight weathering of this dolomite was recorded in the rock cores $[2,13]$.

\subsubsection{Analysis of Data from the Toledo Tunnel}

Based on the described parameters, the tunnel should be analyzed as a vertical recharge flow condition case. According to Heuer (2005), he originally estimated that groundwater inflow in the Toledo Tunnel was approximately $50 \mathrm{gpm}$ (189 L/min). According to Heuer (2005), he inflated his estimate to account for underestimations observed in case studies where radial flow conditions existed. The observed steady state inflow was $30 \mathrm{gpm}$ (114 L/min), as provided by the owner. A correction factor of 1.66 was applied by Heuer in this case [5, 13]. .

An independent analysis was conducted as part of this paper based on raw/original data producing a histogram shown as Fig. 4. This analysis as conducted with raw data from packer tests yields a new, estimated steady state inflow of $30 \mathrm{gpm}$ (114 L/min) as shown in Table 3, which is consistent with observed inflows of $30 \mathrm{gpm}$ as summarized in Table 1 [2, 5, 13].

\subsection{Summary Of Results}

All results presented in this paper for the Elizabethtown and Toledo Tunnel projects are summarized in Table 1. Referring to Table 1, the steady state, groundwater inflow estimates from independent analyses provided in this paper for the Elizabethtown tunnel was 99 gpm, whereas the observed total inflow was $100 \mathrm{gpm}$. Likewise, the steady state, groundwater inflow estimate for the Toledo tunnel was 30 gpm which corresponds to the observed total inflow of $30 \mathrm{gpm}$. Therefore, steady state, groundwater inflow estimates were very, well correlated with observed groundwater inflows for both tunnels using Heuer's semi-empirical procedure from 1995. Heuer's proposed 2005 modifications to the procedure were not applied for reasons discussed in Sect. 5 [13]. 
Table 3

Toledo Tunnel Project - Distribution of Groundwater Inflow Heuer's Procedure using Raw Data [13]

\begin{tabular}{|c|c|c|c|c|c|c|c|c|c|c|c|}
\hline A & B & C & D & $\mathbf{E}$ & $\mathbf{F}$ & G & $\mathrm{H}$ & I & $J$ & $\mathrm{~K}$ & $\mathrm{~L}$ \\
\hline Bin & $\begin{array}{l}\text { Bin } \\
\text { Labels }\end{array}$ & Frequency & $\begin{array}{l}\text { Fraction } \\
\text { Of } \\
\text { Inflow } \\
\text { in } \\
\text { Tunnel } \\
\text { Interval }\end{array}$ & $\begin{array}{l}\text { Length } \\
\text { Of } \\
\text { Tunnel } \\
\text { (m) }\end{array}$ & $\begin{array}{l}\text { Fraction } \\
\text { Of } \\
\text { Tunnel } \\
\text { Length } \\
\text { (m) }\end{array}$ & $\begin{array}{l}\text { Equivalent } \\
\text { Permeability } \\
(\mathrm{cm} / \mathrm{sec})\end{array}$ & $\begin{array}{l}\text { Constant } \\
\left(\mathrm{q}_{\mathrm{s}} / \mathrm{H}\right)\end{array}$ & $\begin{array}{l}\text { Head } \\
(\mathrm{m})\end{array}$ & $\begin{array}{l}\mathrm{q}_{\mathrm{s}} \\
(\mathrm{L} / \mathrm{min} / \mathrm{m})\end{array}$ & $\begin{array}{l}\text { Steady } \\
\text { State } \\
\text { Inflow } \\
\text { (L/min) }\end{array}$ & $\begin{array}{l}\text { Steady } \\
\text { State } \\
\text { Inflow } \\
\text { (gpm) }\end{array}$ \\
\hline Less & $\begin{array}{l}<1.0 \mathrm{E}- \\
06\end{array}$ & 0 & 0.00 & 457 & 0 & $6.50 \mathrm{E}-07$ & 1.30E-04 & 14 & 1.82E-03 & 0 & 0 \\
\hline $\begin{array}{l}3.00 \mathrm{E}- \\
06\end{array}$ & $\begin{array}{l}1.0 \mathrm{E}- \\
06 \text { to } \\
3.0 \mathrm{E}- \\
06\end{array}$ & 2 & 0.11 & 457 & 48 & $2.00 \mathrm{E}-06$ & 4.00E-04 & 14 & 5.60E-03 & 0 & 0 \\
\hline $\begin{array}{l}1.00 \mathrm{E}- \\
05\end{array}$ & $\begin{array}{l}3.0 \mathrm{E}- \\
06 \text { to } \\
1.0 \mathrm{E}- \\
05\end{array}$ & 0 & 0.00 & 457 & 0 & $6.50 \mathrm{E}-06$ & $1.30 \mathrm{E}-03$ & 14 & $1.82 \mathrm{E}-02$ & 0 & 0 \\
\hline $\begin{array}{l}3.00 \mathrm{E}- \\
05\end{array}$ & $\begin{array}{l}1.0 \mathrm{E}- \\
05 \text { to } \\
3.0 \mathrm{E}- \\
05\end{array}$ & 6 & 0.32 & 457 & 144 & 2.00E-05 & 4.00E-03 & 14 & 5.60E-02 & 8 & 2.1 \\
\hline $\begin{array}{l}1.00 \mathrm{E}- \\
04\end{array}$ & $\begin{array}{l}3.0 \mathrm{E}- \\
05 \text { to } \\
1.0 \mathrm{E}- \\
04\end{array}$ & 8 & 0.42 & 457 & 192 & $6.50 \mathrm{E}-05$ & 1.30E-02 & 14 & 1.82E-01 & 35 & 9.3 \\
\hline $\begin{array}{l}3.00 E- \\
04\end{array}$ & $\begin{array}{l}1.0 \mathrm{E}- \\
04 \text { to } \\
3.0 \mathrm{E}- \\
04\end{array}$ & 2 & 0.11 & 457 & 48 & 2.00E-04 & 4.00E-02 & 14 & 5.60E-01 & 27 & 7.1 \\
\hline $\begin{array}{l}1.00 \mathrm{E}- \\
03\end{array}$ & $\begin{array}{l}3.0 \mathrm{E}- \\
04 \text { to } \\
1.0 \mathrm{E}- \\
03\end{array}$ & 1 & 0.05 & 457 & 24 & $6.50 \mathrm{E}-04$ & 1.30E-01 & 14 & $1.82 E+00$ & 44 & 11.6 \\
\hline More & $\begin{array}{l}>1.0 \mathrm{E}- \\
03\end{array}$ & $\begin{array}{l}\text { Not } \\
\text { Observed }\end{array}$ & & & & & & & & & \\
\hline Total & & 19 & 1.00 & & 457 & & & & $\begin{array}{l}\text { Total } \\
\text { Inflow = }\end{array}$ & 114 & 30 \\
\hline
\end{tabular}

\subsection{Normally Distributed Data}

Histograms of packer test data from tunnels representing the vertical recharge flow condition such as Elizabethtown and Toledo projects indicate a classical normal distribution. Based on the results of estimates derived in this paper in comparison to observed inflows, no further refinement in Heuer's procedure for the vertical recharge flow condition is recommended at this time [13].

\subsection{Discussion Of Results}

In 2005, Heuer proposed changes to his 1995 method to improve the accuracy of case study results. However, those changes were based on assumptions and interpretations of other case studies which pertained to deep rock tunnels associated with the radial flow condition [8, 13 , 15].

Heuer calculated groundwater inflows in 2005 for the Elizabethtown tunnel utilizing his 1995 method but assumed that the vertical recharge condition existed in one portion of the Elizabethtown tunnel while the radial flow condition existed in another portion of the tunnel. Under this assumption, the groundwater inflow was calculated to be $66 \mathrm{gpm}$ ( $250 \mathrm{~L} / \mathrm{min})$ as summarized in Table 1 . The observed groundwater 
inflow was $100 \mathrm{gpm}$, therefore, Heuer's estimate was approximately 50 percent below the observed inflow. The analysis utilizing Heuer (1995) method produced an underestimation with the above assumption $[8,13,15]$.

Previously, Heuer had observed underestimations in case study analyses where the radial flow condition existed. These observations are presented and discussed in the paper entitled, " A Geostatistical Solution to Estimating Groundwater Inflows in Deep Rock Tunnels with Validation through Case Studies" [15]. One such case study analysis from this paper was performed for the Chattahoochee tunnel in Georgia. The Chattahoochee tunnel is approximately 49,622 feet (15,125 meters) long with an excavated diameter of 18 feet (5.5 meters). The depth of the tunnel ranges from 100 to 350 feet (31 to 107 meters) below ground surface. A TBM was used to excavate the tunnel. A total of 367 packer tests were performed along the alignment of the Chattahoochee tunnel at the depth of the tunnel. The Chattahoochee tunnel was divided into a north and south drive and Heuer similarly analyzed each drive separately and the results of each analysis added together to determine a total inflow. The north drive extends approximately 25,852 feet (7880 meters), while the south drive extends approximately 23,770 feet (7245 meters). The number of packer tests performed in the north drive was much larger that the south drive. The estimated groundwater inflow for the Chattahoochee tunnel was $900 \mathrm{gpm}$. The observed inflow was approximately $1400 \mathrm{gpm}$. Therefore, the estimated inflow was approximately 50 percent below the observed inflow. This is the same underestimate observed in the Elizabethtown tunnel. However, each underestimate is produced for different reasons. The histograms of each tunnel drive of the Chattahoochee tunnel showed that the data was log normally distributed. When a histogram is created from small sampling programs and the resulting histogram is log normal, it is possible that the extreme, right-end of the log normal, permeability distribution may be underrepresented. The extreme right-end of the log normal distribution, although, representing a very small fraction of the total distribution, could account for a large proportion of the total inflow. In Vanarelli's 2008 and 2020 papers, it was observed and shown that small sampling programs could impact the inflow estimates producing lower estimates. Other case studies where the radial flow condition existed also produced lower groundwater inflow estimates [11, 13-15].

Heuer (2005) concluded that his 1995 method needed to be adjusted, since all his case studies produced underestimates in groundwater inflow. Ultimately, Heuer proposed that the final estimate produced by his 1995 method be multiplied by a correction factor of 1.5 . At the time of his 2005 publication, he could not explain the cause of these discrepancies. As in the Elizabethtown tunnel project, Heuer decided to inflate his estimate (e.g., $30 \mathrm{gpm}$ ) for the Toledo tunnel in order to accurately predict groundwater inflow, but the result overestimated the inflow (e.g.,50 gpm) [2, 7, 8, 13].

In cases where the vertical recharge condition existed, overestimations were produced when Heuer inflated his estimate because he either misinterpreting the hydrogeologic constraints or applied a correction factor when none was necessary. In cases where the radial flow condition existed, underestimations were produced when an insufficient number of packer tests were performed to sufficiently characterized the hydrogeologic nature of the rock formation. The results of each analysis produced similar discrepancies but for different reasons. This paper attempts to explain the reasons for discrepancies in the inflow estimates and to clarify when Heuer 1995 method can provides reasonable estimates of groundwater inflow[13-15].

\subsection{Conclusions}

The Elizabethtown and Toledo tunnels represented cases where the vertical recharge flow condition controlled the amount of groundwater inflow into these shallow rock tunnels. These two cases would indicate the method could yield reliable estimates of groundwater inflow to a shallow rock tunnel. Heuer's semi-empirical procedure as originally proposed by Heuer (1995) can be used without modification to predict groundwater inflows to shallow rock tunnels. The analyses described herein validate a simple, reliable procedure for estimating steady-state, groundwater inflows in shallow rock tunnels $[7,13]$.

\section{Declarations}

\section{Compliance with Ethical Standards}

Conflict of Interest: The author declares that there are no conflicts of interest.

\section{Acknowledgement}

I would like to dedicate this work to Dr. Ronald E. Heuer who developed this semi-empirical procedure and provided raw data and guidance in the analysis of the procedure. This author is greatly indebted to Dr. Heuer as he also served on this author's PhD committee. The author also would like to thank Drs. Kadri Dagdelen and Jamal Rostami of the Colorado School of Mines for their insightful comments, which greatly improved this manuscript. 


\section{References}

1. Chen, R (2010) Groundwater Inflow into Rock Tunnels. Dissertation, University of Texas - Austin.

2. Dawn Engineering. (2005)“Geotechnical Baseline Report-Phase II Eastside Trunk Water Main: Contract B”

3. Farhadian $\mathrm{H}$ and Katibeh H (2017) New Empirical Model to Evaluate Groundwater flow into Circular Tunnel using Multiple Regression Analysis. International Journal on Mining Science and Technology. DOI: 10.1016/j.jimst.2017.03.005

4. Fetter, CW, Applied Hydrogeology, Charles E. Merrill Publishing Company, 1980

5. Goodman, RE, Moye DG, Van Schalkwyk A, and Javandel I. (1964) “Groundwater inflows during tunnel driving”. Annual Meeting of the Association of Engineering Geologists, p. 39-56

6. Hassania AN, Farhadian H, and Katibeh H (2018) A Comparative Study on Evaluation of Steady-state Groundwater Inflow into a Circular Shallow Tunnel. Tunnelling and Underground Space Technology, 73 (2018) 15-25

7. Heuer, RE (1995) “Estimating rock tunnel water inflow”, in G.E., Williamson and I.M. Gowring, Proceedings from Rapid Excavation and Tunneling Conference (RETC), p. 41-60

8. Heuer, RE (2005) “Estimating Rock Tunnel Water Inflow - II”. Proceedings from Rapid Excavation and Tunneling Conference (RETC), p. 394-407

9. Jenny Engineering Company. (2004) “Geotechnical Data Report for Construction, 72-inch East Transmission Reinforcements Phase II, Elizabethtown Water Company"

10. Katibeh H and Aalianvari . (2012) Common Approximations to the Water Inflow into Tunnels. In: Javaid MS (ed) Drainage Systems, p. 75-88

11. Raymer JH (2001) "Predicting groundwater inflow into hard-rock tunnels: Estimating the high-end of the permeability distribution", in W.H. Hansmire and I.M. Gowring. Proceedings: Rapid Excavation and Tunneling Conference, p. 1027-1038.

12. Raymer JH (2005) "Groundwater Inflow into Hard Rock Tunnels: A New Look at Inflow Equations". Proceedings from Rapid Excavation and Tunneling Conference, p. 457-468.

13. Vanarelli, MJ (2007) "Improvements to the Current State of the Practice in Steady-State, Groundwater Inflow Estimates into Rock Tunnels based on the Application of Statistical Analysis Methods of Packer Test Data obtained from Exploratory Borings During Geotechnical Site Investigations" PhD Thesis, Colorado School of Mines.

14. Vanarelli MJ (2008) Statistical Determinations of Steady-State, Groundwater Inflow in Rock Tunnels for the Radial Flow Condition. ASCE/Environmental and Water Resources Institute, Proceedings of the World Environmental \& Water Resources Congress, Honolulu, Hawaii, Ahupua'a: Sustainability from the Mountains to the Sea https://doi.org/10.1061/40976(316)637

15. Vanarelli, MJ, (2020) "A Geostatistical Solution to Estimating Groundwater Inflows in Deep Rock Tunnels with Validation through Case Studies". Mining, Metallurgy and Exploration 38:347-357. https://doi.org/10.1007/s42461-020-00321-7

\section{Figures}


A. Vertical Recharge

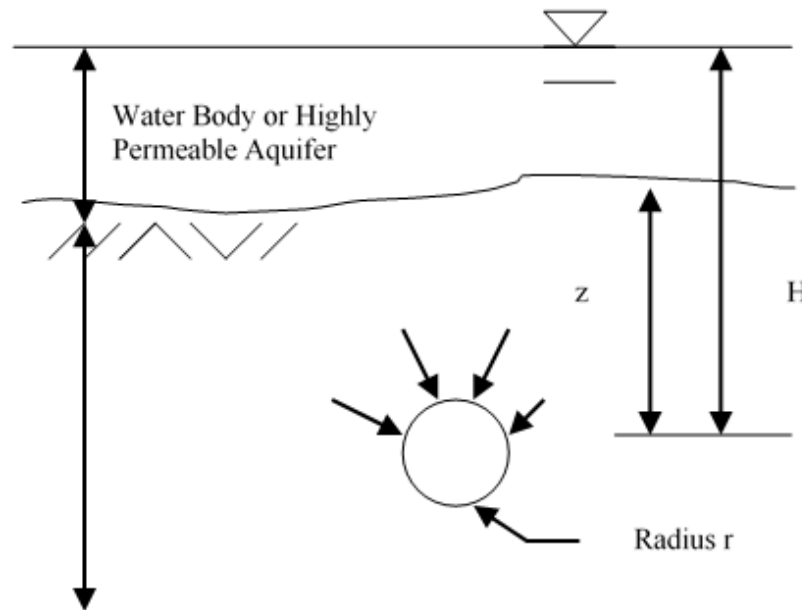

B. Radial Flow

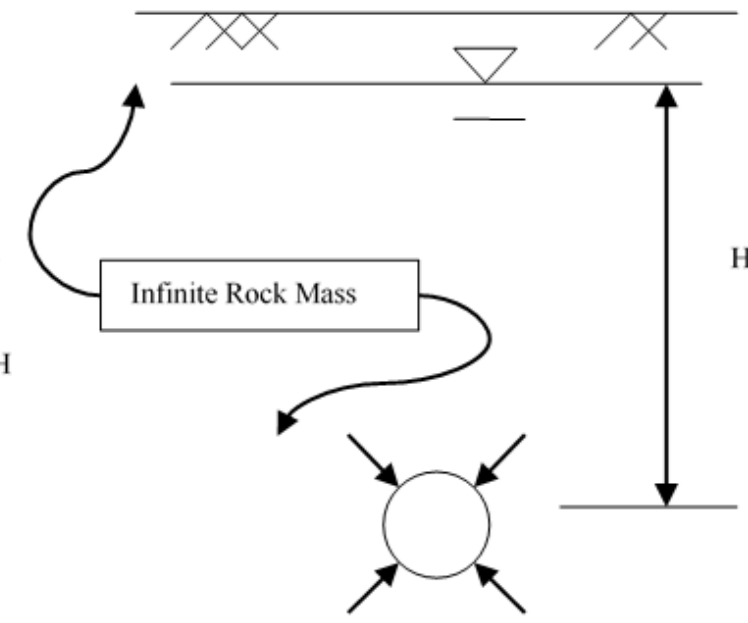

Rock Mass

\section{Figure 1}

Conceptual Models: Steady State Limiting Cases [7]

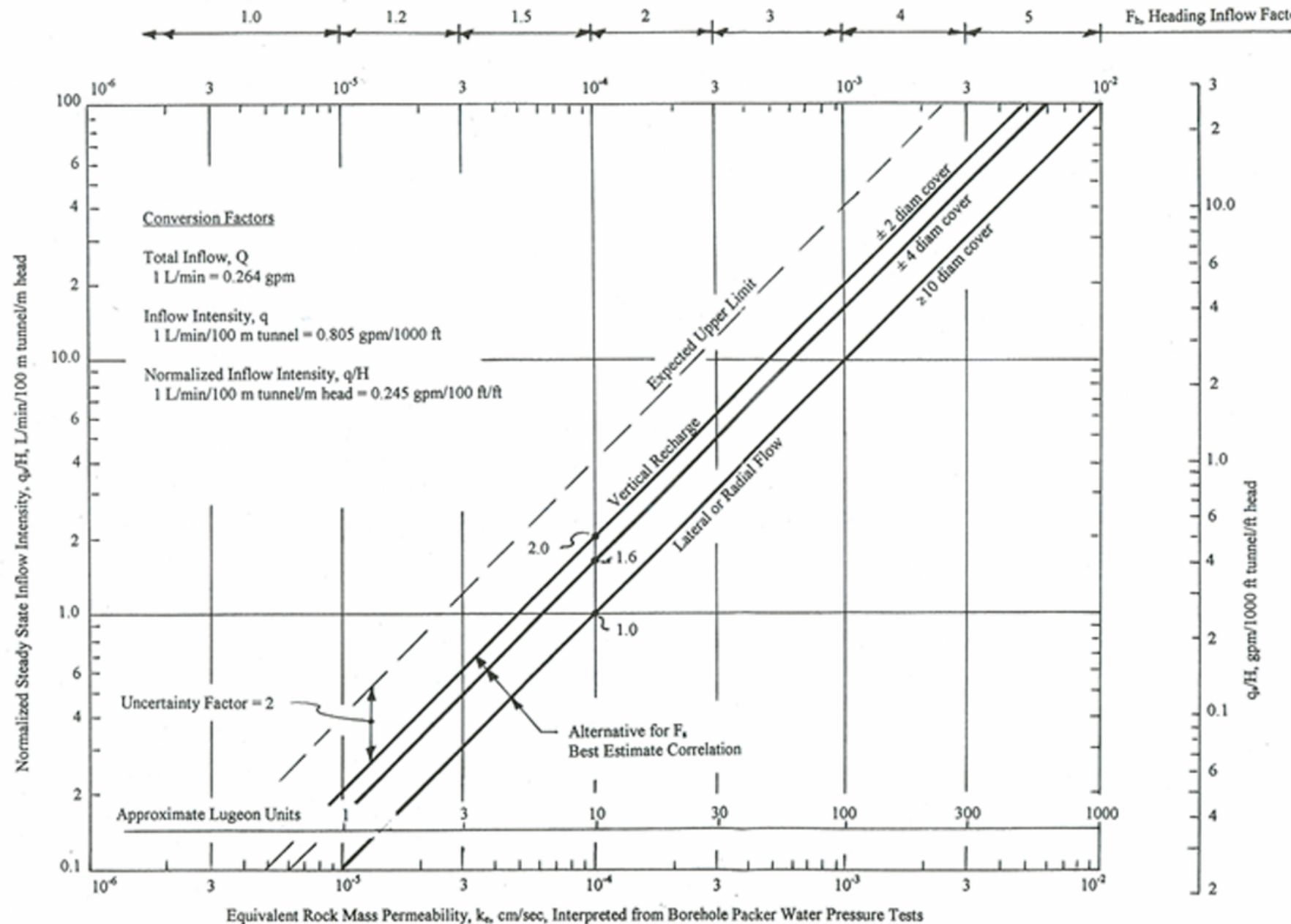


Figure 2

Relationship between Steady State Inflow and Equivalent Permeability $[7,8]$

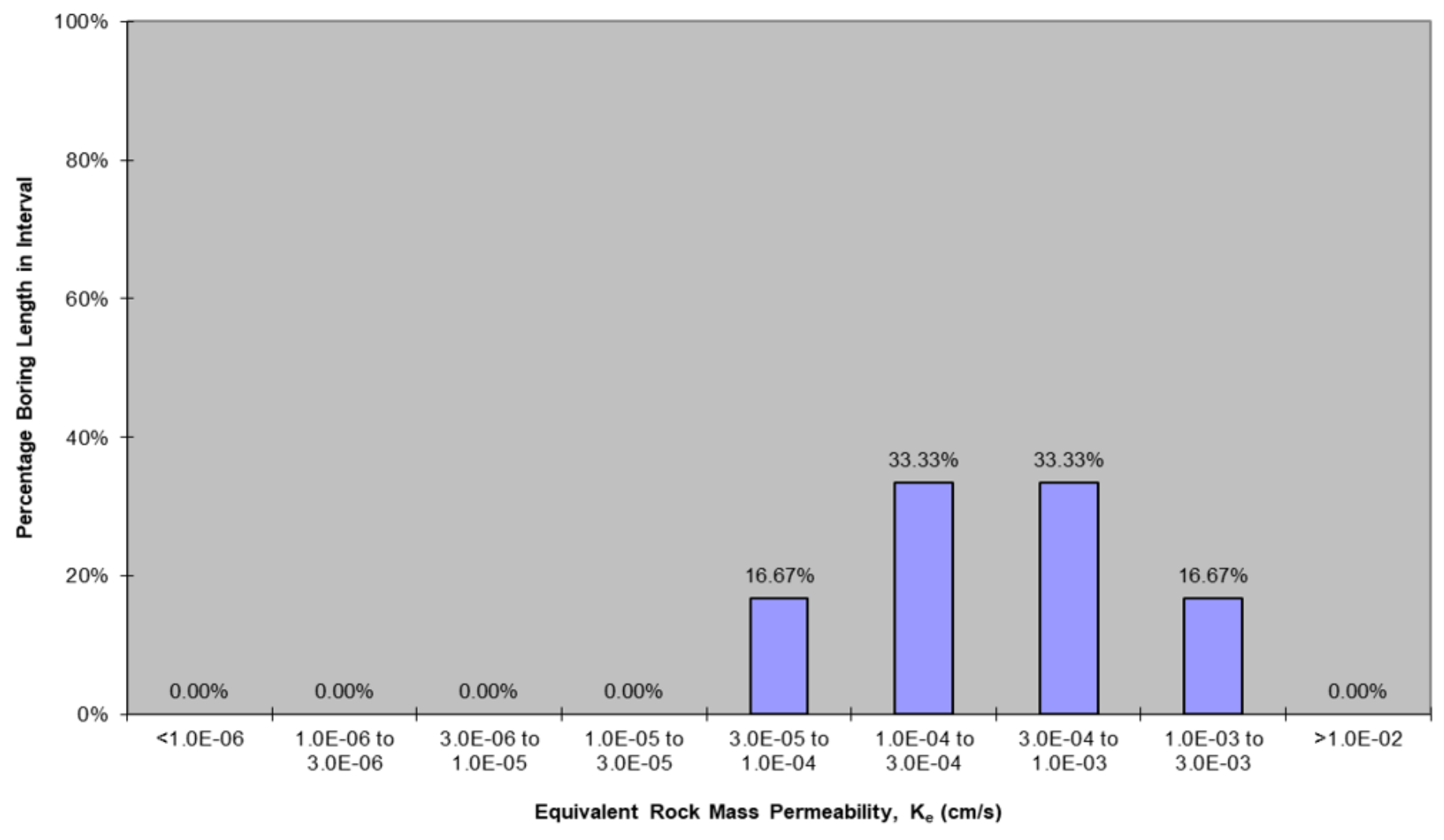

Figure 3

Histogram of Packer Test Results - Elizabethtown [13] 


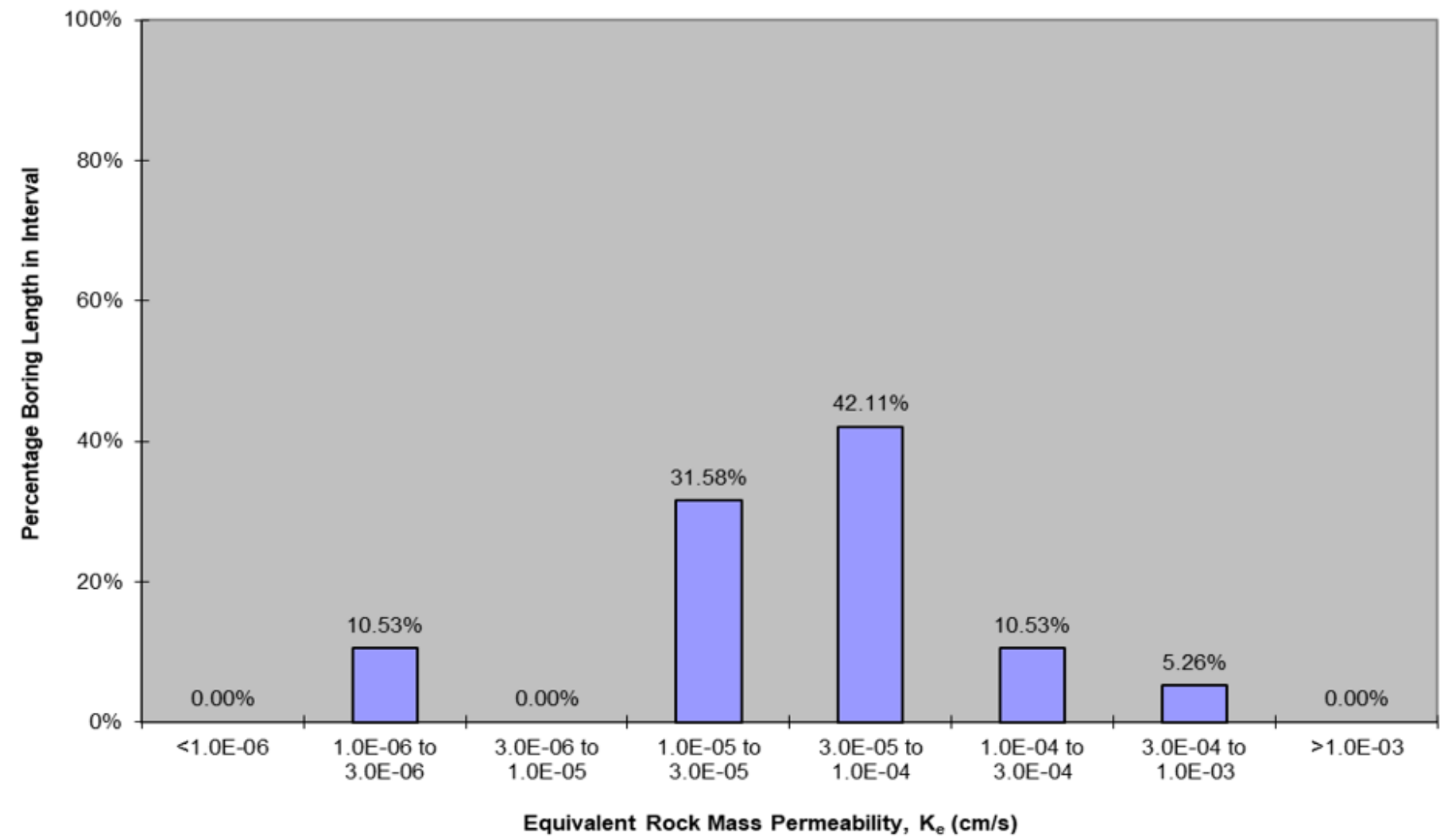

\section{Figure 4}

Histogram of Packer Test Results - Toledo [13] 